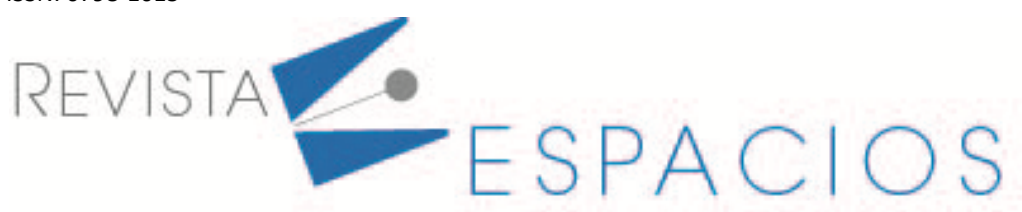

\title{
Models for the normative consolidation of the constitutional and legal status of the municipal police in the Russian Federation
}

\section{Modelos para la consolidación normativa del estado legal y constitucional de la policía municipal en la Federación Rusa}

\author{
ALEKSEEV, Igor A. ${ }^{1}$ \\ MIRZOYAN, Irina A. ${ }^{2}$
}

\begin{abstract}
The article is devoted to the comparative legal analysis of normative legal acts of general and specialized nature, which indirectly or directly fix the constitutional and legal status of the grass-roots level of public order protection bodies-the Municipal Police. The relevance of this research is explained by the fact that local self-government bodies are classified as subjects of public order protection in the Russian Federation through the establishment of Municipal Police, after the adoption of a specialized law. The conducted comparative legal research allowed us to identify existing models of normative consolidation of the constitutional and legal status of the Municipal Police in accordance with the form of state structure.
\end{abstract}

Key words: local self-government, municipal police, public order protection, form of government.

\begin{abstract}
Resumen
El artículo se centra en el análisis jurídico comparativo de los actos jurídicos normativos de carácter general y especializado que establecen de manera indirecta o directa la situación constitucional y jurídica del nivel básico de los órganos de orden público: la policía municipal. La relevancia de esta investigación se debe a que los gobiernos locales se clasifican como agentes de orden público en la Federación Rusa mediante la creación de la policía Municipal después de la aprobación de la ley especial sobre la policía Municipal. El estudio jurídico comparativo ha permitido identificar los modelos existentes de consolidación normativa de la situación constitucional y jurídica de la policía municipal, de acuerdo con la forma de la estructura estatal.

Palabras clave: autogobierno local, policía municipal, protección del orden público, forma de gobierno.
\end{abstract}

\section{Introduction}

The normative consolidation of the constitutional and legal status of the Municipal Police, as the object of research, is of great interest in view of the fact that local self-government bodies belong to the grass-roots level of public order protection bodies. This object is of double interest due to the fact that the functions to maintain

\footnotetext{
1 Ph.D. (Law), Associate Professor of the Department of Constitutional and Municipal Law at Pyatigorsk State University, Pyatigorsk, Russia; e-mail: alekseev12-06@yandex.ru

2 Senior Lecturer, Department of Theory of State and Law at Pyatigorsk State University, Pyatigorsk, Russia; e-mail: mirzoyan-i@mail.ru
} 
public order in the Russian Federation are assigned to local self-government bodies at the constitutional level (Article 132 of the Constitution of the Russian Federation, Mukhametgaliyeva, 2017).

The Basic Law of the State establishes a general and the most important social relationships, it applies to the constitutional functions of local government that received its further development in the provisions of the Federal Law № 131 of 6 October 2003: "On General Principles of Organization of Local Government in the Russian Federation" (Legal reference system ConsultantPlus, 2003), articles 15 and 16 of which are assigned to urban districts and municipal areas as a matter of local importance, the protection of public order through the creation of Municipal Police. At the same time, art. 83 (3) of the said Law indicate that the provisions of the abovementioned articles come into force after the adoption of a Federal Law defining the procedure for organizing and operating the Municipal Police. Today, in Russian reality, there are some successful examples of the functioning of Municipal Police, including Cossack guards. As a rule, everything is limited to funding one or more positions in the system and structure of the Ministry of Internal Affairs. The study of foreign experience in law enforcement and legislative regulation will allow to offer the most successful practical solutions for Russian realities.

In particular, according to article 22 of the Constitution of the Bolivarian Republic of Venezuela (Russian Legal Channel: the Library of Pashkov, 2014), the integrated police system is under the authority of the Ministry of the People's Power for Internal Affairs, Justice and Peace, which is responsible for the security of citizens, and consists of

1. The Ministry of People's power, which is in charge of the security of the citizens.

2. The Bolivarian National Police Force.

3. The forces of the State Police.

4. Municipal Police.

5. National academic institution specializing in security.

6. National Intergovernmental Police Service Foundation.

7. Other bodies and organizations that exercise the exclusive powers of the police service.

8. Any body or entity designated by the national executive power..

According to article 44 of the Organic Law on the police service and the corps of the Bolivarian National Police (Pandectas digital, 2020): "Municipal Police forces are bodies or units responsible for ensuring the security of citizens, responsible for the performance of police services in their territorial space and sphere of competence, focused primarily on prevention and combating crime, strictly subject to established principles, guidelines, and directives issued by the Governing body".

In accordance with article 45, Municipalities may form associations for the provision of police services. Metropolitan Districts and special Districts may not organize police forces or perform police services.

The most obvious normative consolidation of the constitutional and legal status of Municipal police bodies and its relationship with the form of government can be traced on the example of a number of foreign countries. This allows us to distinguish two models of normative consolidation of the constitutional and legal status of the municipal police: federal and unitary. 


\section{Methodology}

As a result of the study of models of the normative constitutional and legal status of the Municipal Police, the methodological basis for the study was formed by such methods as the comparative legal method and the systemic-structural method. Using these methods, the legal systems of various states are considered by comparing state and legal institutions and their basic principles, and the effectiveness of the system of sources of law on the activities of Municipal Police is assessed.

Most states recognize international law and international treaties as part of their national legislation. Acts of an international nature that establish the constitutional legal status of the Municipal Police include acts of a general nature in the field of protection and enforcement of human rights and freedoms: The Universal Declaration of Human Rights; the International Covenant on Civil and Political Rights, and others.

Specialized acts include The Code of Conduct for Law Enforcement Officials (Official website of the United Nations. Human Rights, 1979) and the Guidelines (United Nations Digitally Library, 1989) for this code, The Declaration on the Police (Parliamentary Assembly, 1979), International standards for law enforcement agencies (1996), the Recommendation of the Committee of Ministers of the Council of Europe "On the European Code of Police Ethics" (The UN Refugee Agency, 2001), and others.

The above-mentioned acts are not applicable in all states, but they clearly show the essential content of the normative consolidation of the constitutional legal status of the municipal militia (police) as public order protection bodies, representing a supranational level of consolidation of this status.

\section{Results}

At the state level, normative consolidation of the constitutional and legal status is exercised directly through the main laws of states, as well as through the state legislation (federal laws and laws of unitary states). This study will be based on the normative practice of those states where Municipal Police bodies are already functioning. Examples include Austria, Bolivarian Republic of Venezuela, Brazil, Canada, Italy, Portugal, France, Switzerland, and South Africa.

General constitutional norms include those that allow us to trace the relationship between the constitutional and legal status of the Municipal Police and the democratic principles of the organization of the state system and society as a whole, which are based on respect for human and civil rights and freedoms; norms that establish the basis for the activities of the Municipal Police as local self-government bodies, and therefore public authorities. These principles can be considered universal because they are inherent in democratic states.

The rules of a specialized nature should include the rules that establish the basis for the activities of public order agencies, as well as various requirements, as specified in the Constitution of Austria (2020). Paragraph 2 article 118 , wich states that communities are responsible for performing public administration tasks in their own area of competence, including both the local security police and the local police that ensure order when carrying out any activities on the territory of municipalities.

The Article 272 of the Portuguese Constitution (Official website of Portuguese parliament, 2020) clearly indicates that the functions of the police include the protection of democratic legality, internal security and the rights of citizens. The overall objectives of the police service are enshrined in the Constitution of the Republic of South Africa in article 205(South Africa Government, 2020), which includes the prevention, investigation of crimes, as well as combating crime for the purpose of maintaining public order, the protection of the state's citizens, their property, and the observance and enforcement of laws. 
This should also include constitutional norms that directly establish the possibility of setting up Municipal Police bodies at the local level. Article 144 of the Brazilian Constitution (Presidency of the Republic. Civil House for Legal Affairs, 2020) grants municipalities the right to create a municipal guard, which is established to protect municipalities, their property and infrastructure. Article 15 of the Austrian Constitution states that the functions of the municipal security police are provided by the community.

The Constitution of South Africa also provides for the possibility of creating police services at the local government level, if necessary, which is reflected in part 2 of article 205. In turn, part 7 of article 206 stipulates that national legislation should provide the basis for the creation, powers, functions and control of Municipal Police services.

Consider the federal and unitary models of normative consolidation of the constitutional and legal status of the Municipal Police.

General federal laws include the Federal Law "On the Organization of Security Management and Security Police Activities" (Federal legal information system of Austria (RIS), 2020), which addresses general issues of police organization in the state, as well as the activities of the local security police (Municipal Police). Focusing on the specialized federal legislation, we can single out the Law of Brazil No. 13.022 of 8 August 2014 "On the general charter of the Municipal Guard" (Jusbrasil Website, 2020), which establishes the basis for the organization and activities of the Municipal Guard in Brazil.

The unitary model assumes the existence of state laws of general and specialized orientation. France has adopted the General Code of Local Authorities (Official website of the legislation of the French Republic, 2017). Thus, article L2212-2 defines the goals of the Municipal Police, which the legislator refers to ensuring public order, safety, security and sanitation. This can also include the Code of National Security (Official website of the legislation of the French Republic, 2017).

The status of the local police is regulated by general and specialized legislation in Portugal. Portuguese Law No. 176/2013 (Electronic journal of Portuguese legislation, 2020) establishes the legal regime of local authorities, as well as inter-territorial associations, and the procedure for delegating state powers to local authorities. In addition, Portugal has a special Framework Law defining the mode and form of a community police No. 19/2004 (Electronic journal of Portuguese legislation, 2020), such a specialized Framework Law of Italy on regulation of the Municipal Police of 07 March 1986 (Official website of the legislation of the Italian Republic, 2020).

Within the framework of the Federal model, it is necessary to highlight the regional level of securing the constitutional and legal status of the Municipal Police through the fundamental acts of the federal subjects and regional legislation.

The Constitution of the Canton of Basel-Land, Switzerland (Collection of legislation of the Canton of Basel-Land, 2018), contains norms of a general orientation, indicating in article 44 the independence of municipalities from state power, thereby consolidating the competence of municipalities in various spheres of public life.

In addition to the rules of a general character in the field of constitutional legal status of Municipal Police there are specialized norms. In Switzerland, article 27 of the Constitution of the Canton of Aargau (Official website of the state Chancellery of Aaragau, 2019) assigns to the Canton and Municipalities the duty to ensure public order and security. The Constitution of the Canton of Lucerne (Systematic collection of laws (SRL) of the Canton of Lucerne, 2014) defines the tasks of protecting public order and security within the municipality as the tasks of municipalities (article 11). The Constitution of the state of Rio de Janeiro in Brazil (Official website of the government of the state of Rio de Janeiro, 2000) grants municipalities the right to establish a municipal guard (article 183). 
The British Columbia Police Act can be singled out as specialized regional acts (Official website of the Canadian legislation, 2019). According to part 2 of article 3 of Chapter 2 of the Law, Municipal Police bodies are established in municipalities with a population of more than 5 thousand citizens. In the Canton of Zurich, Switzerland, at the regional level, the Law on Police Organization of 29 November 2004 (Official website of the Canton of Zurich, 2020) and the Law on Police of 23 April 2007 (Official website of the Canton of Zurich, 2020) apply to both the cantonal police and the local police.

Due to the specifics of the state structure of unitary states, the normative consolidation of the constitutional and legal status of the Municipal Police is implemented at the state and administrative territorial level, which includes local self-government bodies. The analysis of the Italian Constitution (Section 5), laws in the field of fixing the status of the Municipal Police shows that due to the specifics of the administrative territorial division of the Italian Republic (i.e. regions, provinces, municipalities), where the provinces act as state territorial units and regional divisions, the regulation of the Municipal Police is carried out at the state and administrative territorial level. In turn, the administrative territorial level includes regional legislation and local legislation, which includes provinces and municipalities. On the basis of article 6 of the Framework Law and article 117 of the Constitution of the Republic of Italy, which vested the regions, as administrative units, powers to issue normative legal acts in various areas, a number of regional laws have been adopted that are responsible for regulating the status of the Municipal Police.

For example, in the region of Sardinia, the Law No. 9 of 22 August 2007, "Regulations of the local Police and Regional Security policy" (Official website of the Region of Sardinia, 2007) establishes general rules for the activities of the Municipal Police. In the case of provincial legislation, an example is the Province of Bolzano, where there is a specialized law of 10 November 1993 (Official website of the laws of the province of Bolzano, 2020) "Rules of the Municipal Police", which regulates public relations on the activities of the provincial police and consists of 12 articles.

In Portugal, municipal regulations or ordinances on the organization and functioning of the Municipal Police are adopted (Regulations governing the organization and operation of the Municipal Police, 2000). Such municipal legal acts are adopted by the local authorities in the Italian Republic (Official website of the municipality of Padua, 2014).

The Federal model involves the consolidation of the constitutional and legal status of the Municipal Police at the municipal level, for example, the constitutional status of the Municipal Guard of Brazil, in the Municipality of El Salvador, establishes the "Organic Law of the Municipality of Salvador" (Official website of the municipality of Salvador, 2020), which is a fundamental act of the municipality and defines the goals of the creation of the municipal guard.

At the same time, acts of a specialized nature are also adopted at the municipal level, so the activities of the municipal guard in the municipality of Votorantim, state of San Paolo, Brazil, are regulated at the local level by municipal law No. 009 of 18 July 2017 (Complementary Law No. 009, 2017), which establishes general rules for the activities of the municipal guard.

Both models suggest that the status of Municipal Police can be normalized through public law agreements (arrangements and contracts) between levels of public authority, in the case of the federal model, or between territories, in the case of the unitary model.

Section 1, paragraph 3 of the Law on the organization of the police of the Canton of Zurich grants municipalities the right to establish a Municipal Police. Paragraph 4 of the Law grants Municipalities the right to enter into agreements with the Canton for the provision of police services in the territory of the municipality on a costreimbursable basis. 
It is necessary to point to The British Columbia Police Act, chapter 2, article 3 paragraph 2, which establishes the obligation to carry out police activities on the territory of Municipalities with a population of more than 5 thousand people, not only through the establishment of a Municipal Police, but also in the form of a contract with the provincial government or another Municipality for the provision of police services.

The National Security Code of France, in article L5212-1, provides for the possibility of creating a single corps of Municipal Police within several Municipalities. The law of the Province of Bolzano, Italy "Rules of the Municipal Police" also contains provisions on inter-territorial cooperation in the field of police activities.

These contracts have a similar nature to the Russian practice for contracting to provide services for Municipal needs, which have a dual nature - civil law and public law, but the rules of the latter are predominant here. This normative practice is not reflected in the legislation of other states, but this legislation does not prohibit the conclusion of such contracts and the implementation of a number of administrative functions (police functions) by third-party organizations.

\section{Conclusions}

In the substantive part, the norms that establish the constitutional and legal status of the Municipal Police can be divided into general and specialized norms. The federal model of normative consolidation of the constitutional and legal status of the Municipal Police assumes the consolidation of this status at the state level, in addition to constitutional norms, by federal legislation in the form of general or specialized laws. The unitary model of normative consolidation of the constitutional and legal status of the Municipal Police assumes the existence of state laws of general and specialized orientation.

Conducted research reveals another level of normative constitutional legal status of Municipal Police - local, in the form of acts of local importance. The studied rules and instructions are of a detailed nature and aimed at fixing not only the general rules of the Municipal Police, but also a significant number of different procedural issues from arrests to providing medical assistance to victims by police officers.

The information contained in the table below allows to determine the levels of legal regulation, as well as the issues related to the organization and activities of the Municipal Police in the context of legislative regulation and legal application. In fact, it explains what issues are under the jurisdiction of a particular level of government when forming the legislative regulation of the Municipal Police. The information below fully reflects the conclusions obtained as a result of this study, which are presented in tabular form for more convenient use.

A clear division by level of regulation will allow, according to the authors, to more purposefully regulate the existing legal relations in this area. In addition, it will allow the legislator to use the existing foreign experience in Russian reality, depending on the level of legal consideration. 
Table 1

Models for the Normative Consolidation of the

Constitutional and Legal Status of the Municipal Police

\begin{tabular}{|c|c|}
\hline Federal & Unitary \\
\hline \multicolumn{2}{|c|}{$\begin{array}{l}\text { Supranational level - in the form of pacts (public legal agreements), as well as non-binding instruments - } \\
\text { declarations, codes, standards, recommendations, and so on. }\end{array}$} \\
\hline $\begin{array}{c}\text { State level } \\
\text { Basic law (s) of the Federation; } \\
\text { Laws of the Federation of general orientation; } \\
\text { Specialized federal laws. }\end{array}$ & $\begin{array}{c}\text { State level } \\
\text { Basic law (s) of the state; } \\
\text { State laws of general direction; } \\
\text { Specialized laws. }\end{array}$ \\
\hline $\begin{array}{c}\text { Regional level } \\
\text { Basic laws of the federal entities (cantons); } \\
\text { Laws of federal entities (cantons) of general } \\
\text { orientation; } \\
\text { Specialized laws of federal entities (cantons). }\end{array}$ & $\begin{array}{c}\text { Administrative territorial level (local level) } \\
\text { Laws and normative acts of administrative territorial } \\
\text { units of general direction; } \\
\text { Specialized laws and normative acts of administrative } \\
\text { territorial units. }\end{array}$ \\
\hline $\begin{array}{c}\text { Municipal level } \\
\text { Basic acts of municipalities; } \\
\text { Specialized municipal legal acts (regulations, } \\
\text { regulations, etc.). }\end{array}$ & $\begin{array}{l}\text { Inter-territorial level - in the form of agreements and } \\
\text { treaties between administrative divisions (public law } \\
\text { agreements). }\end{array}$ \\
\hline $\begin{array}{c}\text { Intermediary level - agreements and treaties between } \\
\text { different levels of public authority (public law } \\
\text { agreements). }\end{array}$ & $\begin{array}{l}\text { Local level - in the form of regulations, rules, and } \\
\text { instructions. }\end{array}$ \\
\hline Local level - regulations, rules, and instructions. & \\
\hline \multicolumn{2}{|c|}{$\begin{array}{l}\text { Civil law level - in the form of contracts for the provision of police services by third parties, which have a dual } \\
\text { nature (public law and civil law), where the latter norms prevail. }\end{array}$} \\
\hline
\end{tabular}

Source: developed and complied by the authors

\section{References}

Collection of Legislation of the Canton of Basel-Land (2018). Constitution of the Canton of Basel-Landschaft. Retrieved from: http://bl.clex.ch/app/de/texts_of_law/100/versions/2189

Complementary Law No. 009 of 18 July 2017 (2017). Retrieved from:

https://www.votorantim.sp.gov.br/publicos/05_Ic009.pdf

Electronic journal of Portuguese legislation (2020). Portuguese Law No. 19/2004/ Retrieved from: https://dre.pt/pesquisa/-/search/270386/details/maximized

Federal legal information system of Austria (RIS) (2020). Federal law consolidated: Entire legal provision for the Federal Constitutional Law, version of 01.08.2020. Retrieved from:

https://www.ris.bka.gv.at/GeltendeFassung.wxe?Abfrage=Bundesnormen\&Gesetzesnummer=10000138

Electronic journal of Portuguese legislation (2020). Portuguese Law No. 176/2013/ Retrieved from: https://dre.pt/web/guest/pesquisa/-/search/basic?q=176\%2F2013

International standards for law enforcement agencies (1996). Retrieved from:

https://www.ohchr.org/Documents/Publications/training5Add1ru.pdf

Jusbrasil Website (2020). Law 13022/14 / Law No. 13.022, of August 8, 2014. Retrieved from:

https://presrepublica.jusbrasil.com.br/legislacao/133068266/lei-13022-14\#art-1 
Legal reference system ConsultantPlus (2003). Federal law N 131-FZ of 06.10.2003 “On general principles of organization of local self-government in the Russian Federation" (with amendments). Retrieved from: http://www.consultant.ru/document/cons_doc_LAW_44571/

Mukhametgaliyeva, S. K. y Ivanova, N. L. (2017). Human rights protection: the Genesis of public authorities of entities in the Russian Federation. Revista Espacios. Volume 38 (Number 57), page 19. Retrieved from: http://www.revistaespacios.com/a17v38n57/17385719.html

Official website of the legislation of the French Republic (2020). The General Code on Local Authorities. Retrieved from: https://www.legifrance.gouv.fr/codes/id/LEGIARTI000041429920/2021-01-01/

Official website of the legislation of the Italian Republic (2020). The Framework Law on the regulation of the Municipal Police. Retrieved from: https://www.normattiva.it/uri-res/N2Ls?urn:nir:stato:legge:1986-0307;065

Official website of the Canadian legislation (2019). Police Act, RSBC 1996, c 367. Retrieved from: https://www.canlii.org/en/bc/laws/stat/rsbc-1996-c-367/latest/rsbc-1996-c367.html?searchUrlHash=AAAAAQAKUE9MSUNFIEFDVAAAAAAB\&resultIndex=7

Official website of the Canton of Zurich (2020). Law on Police Organization of 29 November 2004. https://www.canlii.org/en/bc/laws/stat/rsbc-1996-c-367/latest/rsbc-1996-c367.html?searchUrlHash=AAAAAQAKUE9MSUNFIEFDVAAAAAAB\&resultIndex=7\%20https://www.zuerich. ch/zh/en/index.html

Official website of the Canton of Zurich (2020). Law on Police of 23 April 2007. Retrieved from: https://www.zuerich.ch/zh/en/index.html

Official website of the state Chancellery of Aaragau (2019). The Constitution of the Canton of Aaragau. Retrieved from: https://gesetzessammlungen.ag.ch/frontend/versions/2720

Official website of the government of the state of Rio de Janeiro (2000). Constitution of the state Rio de Janeiro promulgated on 5 October 1989. Retrieved from:

http://www.dgf.rj.gov.br/legislacoes/Constituicoes/Constituicao_\%20do_\%20Estado_do_\%20Rio_de_Jane iro-2000.pdf

Official website of the municipality of Padua (2014). Urban police regulation and for civil coexistence in city. Retrieved from: http://www.padovanet.it/sites/default/files/attachment/2018_09_24_REGOLAMENTO_DI_POLIZIA_URBA NA_1.pdf

Official website of the municipality of Salvador (2020). Organic Law of the Municipality of Salvador / BA. Retrieved from: https://leismunicipais.com.br/lei-organica-salvador-ba

Official website of the Portuguese Parliament. Retrieved from: https://www.parlamento.pt/Legislacao/Paginas/ConstituicaoRepublicaPortuguesa.aspx

Official website of the laws of the province of Bolzano (2020). Provincial Law N. 9 of 20 April 1993. http://lexbrowser.provinz.bz.it/doc/it/lp-1993-

9/legge_provinciale_20_aprile_1993_n_9.aspx?q=\&a=1993\&n=9\&in=-\&na=

Official website of the Region of Sardinia (2007). Regional Law N. 9 of 22 August 2007. Retrieved from: https://www.regione.sardegna.it/j/v/80?s=54714\&v=2\&c=3311\&t=1 
Official website of the United Nations. Human Rights (1979). Code of Conduct for Law Enforcement Officials (adopted on 17.12 .1979 by Resolution 34/169 at the 106th plenary meeting of the UN General Assembly). Retrieved from: https://www.ohchr.org/en/professionalinterest/pages/lawenforcementofficials.aspx

Pandectas digital (2020). Organic law on the Bolivarian police service and corps national police. Retrieved https://pandectasdigital.blogspot.com/2016/06/ley-organica-del-servicio-de-policia-y.html

Parliamentary Assembly (1979). Resolution N 690. Parliamentary Assembly of the Council of Europe "Declaration on police" (Adopted in Strasbourg on 08.05.1979 at the 31st session of the parliamentary Assembly of the Council of Europe). Retrieved from: http://assembly.coe.int/nw/xml/XRef/XrefXML2HTML-en.asp?fileid=16101

Presidency of the Republic. Civil House for Legal Affairs (2020). Constitution of the 1988 Federative Republic of Brazil. Retrieved from: http://www.planalto.gov.br/ccivil_03/constituicao/constituicao.htm

Regulations governing the organization and operation of the Municipal Police (2000). Retrieved from: https://www.cm-viladoconde.pt/cmviladoconde/uploads/document/file/44/20080812110147300453.pdf

Russian legal channel: the library of Pashkov (2014). Constitution of the Bolivarian Republic of Venezuela of 1999. Retrieved from: https://constitutions.ru/?p=9864

South Africa Government (2020). Constitution of the Republic of South Africa, 1996 - Chapter 11: Security services. Retrieved from: https://www.gov.za/documents/constitution-republic-south-africa-1996chapter-11-security-services\#205

Systematic collection of laws (SRL) of the Canton of Lucerne (2014). Constitution of the canton of Lucerne. Retrieved from: http://srl.lu.ch/app/de/texts_of_law/1/versions/3014

The UN Refugee Agency (2001). Recommendation of the Committee of Ministers of the Council of Europe "On the European Code of Police Ethics" . (Adopted on 19.09.2001 at the 765th meeting of representatives of Ministers). Retrieved from: https://www.refworld.org/docid/43f5c7944.html

United Nations Digitally Library (1989). Guidelines for the effective implementation of "The Code of Conduct for Law Enforcement Officials" (Adopted On 24.05.1989 by Resolution 1989/61 at the 15th plenary meeting of the UN Economic and Social Council). Retrieved from: https://digitallibrary.un.org/record/75546? In=en Attribución-NoCommercial 4.0 International

$(\mathrm{CC}) \mathrm{BY}$-NC 